\title{
Prospects for bioenergy use in Ghana using Long-range Energy Alternatives Planning model
}

Kemausuor, Francis; Nygaard, Ivan; Mackenzie, Gordon A.

Published in:

Energy

Link to article, DOI:

10.1016/j.energy.2015.08.104

Publication date:

2015

Document Version

Peer reviewed version

Link back to DTU Orbit

Citation (APA):

Kemausuor, F., Nygaard, I., \& Mackenzie, G. A. (2015). Prospects for bioenergy use in Ghana using Long-range Energy Alternatives Planning model. Energy, 93(Part 1), 672-682. https://doi.org/10.1016/j.energy.2015.08.104

\section{General rights}

Copyright and moral rights for the publications made accessible in the public portal are retained by the authors and/or other copyright owners and it is a condition of accessing publications that users recognise and abide by the legal requirements associated with these rights.

- Users may download and print one copy of any publication from the public portal for the purpose of private study or research.

- You may not further distribute the material or use it for any profit-making activity or commercial gain

- You may freely distribute the URL identifying the publication in the public portal 


\title{
Prospects for bioenergy use in Ghana using Long Range Energy Alternative Planning model
}

\author{
by \\ Francis Kemausuor $^{1,2}$; Ivan Nygaard ${ }^{3}$; Gordon Mackenzie ${ }^{3}$ \\ ${ }^{1}$ Department of Agricultural and Biosystems Engineering, Kwame Nkrumah University of Science \\ and Technology (KNUST), Kumasi, Ghana \\ ${ }^{2}$ The Brew-Hammond Energy Center, KNUST, Kumasi, Ghana \\ ${ }^{3}$ UNEP DTU Partnership, Department of Management Engineering, Technical University of Denmark \\ (DTU), Copenhagen, Denmark \\ fkemausuor.soe@knust.edu.gh; ivny@dtu.dk; goma@dtu.dk
}

Post print version of paper published in

Energy 93 (2015) 672-682

http://dx.doi.org/10.1016/j.energy.2015.08.104

Available at

http://www.sciencedirect.com/science/article/pii/S0360544215011810

\begin{abstract}
As Ghana's economy grows, the choice of future energy paths and policies in the coming years will have a significant influence on its energy security. A Renewable Energy Act approved in 2011 seeks to encourage the influx of renewable energy sources in Ghana's energy mix. The new legal framework combined with increasing demand for energy has created an opportunity for dramatic changes in the way energy is generated in Ghana. However, the impending changes and their implication remain uncertain. This paper examines the extent to which future energy scenarios in Ghana could rely on energy from biomass sources, through the production of biogas, liquid biofuels and electricity. Analysis was based on moderate and high use of bioenergy for transportation, electricity generation and residential fuel using the LEAP model. Results obtained indicate that introducing bioenergy to the energy mix could reduce GHG emissions by about 6 million tonnes $\mathrm{CO}_{2}$ e by 2030, equivalent to a $14 \%$ reduction in a businessas-usual scenario. This paper advocates the use of second generation ethanol for transport, to the extent that it is economically exploitable. Resorting to first generation ethanol would require the allocation of over 580,000 ha of agricultural land for ethanol production.
\end{abstract}

Keywords: Prospects, bioenergy, Ghana, LEAP 


\section{INTRODUCTION}

Ghana's energy sector is faced with two principal challenges: the inability to provide adequate electricity generation capacity to ensure reliable power supply (Mensah et al., 2014) and the increased use of woodfuels as main cooking fuel for close to $80 \%$ of households who do not have access to modern cooking fuels (Ghana Statistical Service, 2012). The country's electricity generation infrastructure, which in the past relied mainly on cheaper hydropower, is increasingly shifting towards more expensive thermal generation. Low water inflows into the hydro dams and increasing cost of crude oil has resulted in intermittent power supply as government struggles to purchase fuel to run the thermal plants. Meanwhile, even though there has been recent decline, the general trend in the cost of crude oil over the past few decades suggest further price increases, especially as fossil fuel reserves are gradually being used up with fewer new discoveries (Shafiee and Topal, 2009). This has led to the extraction of crude oil and natural gas from 'unconventional' reserves such as tar sands and shale formations which were previously untouched for environmental reasons (Charpentier et al., 2009; Brasier et al., 2011; Vidic et al., 2013). Other factors, such as the irregularities in supplies and distribution, the challenges of accessing and procuring unconventional fuels, and occasional political instabilities in major supply regions, have caused general uncertainty regarding global reliability on fossil fuels in the coming decades (Fisk, 2013; Hughes and Lipscy, 2013; Nathan et al., 2013).

The cooking fuel sector in Ghana is dominated by woodfuels. As of the year 2010, about $75 \%$ of households in the country rely on traditional biomass as main cooking fuel with only $18.2 \%$ using gas as the main ${ }^{1}$ fuel (Ghana Statistical Service, 2012). Whereas the effect of woodfuel use on deforestation is debatable ${ }^{2}$, the impact of kitchen smoke emissions on the health of women and children is a generally accepted fact (Smith et al., 2014; Perez-Padilla et al., 2010).

Transport fuels in Ghana are wholly dependent on petroleum products with implications for greenhouse gas (GHG) emissions in the country. Energy sector emissions in the country represent the fastest growing source of GHG emissions and accounted for $41 \%$ of emissions in 2006 (EPA-Ghana, 2011a). Between 1990 and 2006, energy sector emissions increased by $183 \%$, from $3.3 \mathrm{MtCO}_{2} \mathrm{e}$ in 1990 to $9.2 \mathrm{MtCO}_{2} \mathrm{e}$ in 2006 (EPA-Ghana, 2011a). Within the energy sector, transport was the largest source of emissions with about $43 \%$. Increase in fuel consumption within the transport sector was due to increasing vehicle fleets and poor fuel efficiency (EPA-Ghana, 2011b).

To ameliorate the situation, the Parliament of the Republic of Ghana enacted a Renewable Energy Act in 2011 (RE Act) in order to promote the increased use of renewable energy. The principal aim of the RE Act is to provide for the development, management, utilization, sustainability and adequate supply of renewable energy for electricity generation, transportation and residential fuel use in Ghana. The RE Act set a 10\% target for renewable

\footnotetext{
${ }^{1}$ A household using LPG as main cooking fuel could still be using other fuels such as charcoal and firewood when the need arises.

${ }^{2}$ While use of woodfuel for cooking has been perceived by some authors and development agencies as leading to deforestation, today most scholars agree that agriculture and the logging industry are the main drivers for the observed decreasing forest vegetation in most developing countries, and that use of wood fuel is mainly causing local effects around big cities (Arnold et al, 2006). For more details in this debate, see for example Hiemstravan der Horst and Hovorka, (2009), Mwampamba et al, (2013), Hansfort and Mertz (2011), Gazull and Gautier (2014). Scientific literature on linkages between woodfuel use and deforestation in Ghana is limited. However, in research on reasons for deforestation in the tropical area in Ghana, Appiah et al. (2009) do not mention woodfuel among the four most significant drivers for decreased forest cover.
} 
electricity (from solar, wind, mini-hydro and biomass) in the national electricity mix by 2020 . With regard to fuels, the RE Act calls for the promotion of increased use of improved bioenergy technologies as well as support for the use of biomass resources through legislation, fiscal incentives and attractive packages. An incoming bioenergy legislation calls for $10 \%$ biofuels in transportation mix by 2020 and $20 \%$ by 2030 . A gradual shift to domestically produced renewable fuels has the potential to create employment, ensure energy security and reduce GHG emissions.

Recent studies have sought to establish to what extent biomass from crop and forestry residue, manure and municipal waste could contribute to the energy supply mix in Ghana. Kemausuor et al. (2014) estimate about 97 PJ per year of bioenergy from crop residues, forest residues, manure, municipal solid and liquid wastes. Estimates by Mohammed et al. (2013) and Duku et al. (2011) also place bioenergy potentials from crop residues at between 75 and 100 PJ and about 48 PJ from animal manure. Biomass is a versatile fuel that can provide not only electricity, but also transport and residential heating fuels. It is therefore worth exploring to what extent this could be possible in Ghana, going into the future.

Although bioenergy has a lot to offer in the energy mix, existing energy plans by relevant agencies have failed to capture the extent to which bioenergy could support the energy mix in Ghana (see for example, Ministry of Energy, 2006; Energy Commission, 2006). The newly approved RE Act, combined with increasing demand for energy has created an opportunity for dramatic changes in the way energy is generated in Ghana. However, the impending changes and their implication remain uncertain. In view of the above, this study explores the extent to which future energy scenarios in Ghana could rely on modern biomass energy. The study performs analysis based on moderate and high use of bioenergy in the transportation, electricity generation and residential sectors and determines their possible impacts on Ghana's energy system. Key indicators are: bioenergy substitution of fossil fuels; bioenergy substitution of traditional biomass; change in diversity of energy supply; and environmental benefits (GHG emission reduction).

\section{METHODOLOGY}

The study was conducted using the Long-Range Energy Alternatives Planning (LEAP) model. LEAP is a scenario-based energy-environment modelling tool for energy policy analysis and climate change mitigation assessment. LEAP can be used to track energy consumption, production and resource extraction in all sectors of an economy as well as account for greenhouse gas (GHG) emissions from energy demand and conversion (Bautista, 2012; Shin et al., 2005; McPherson and Karney, 2014). The model was developed by the Stockholm Environment Institute (SEI-US), based in Boston, Massachusetts ${ }^{3}$. LEAP can be applied at different scales ranging from cities and states to national, regional and global applications (Suganthi and Samuel, 2012). The LEAP model was chosen among various other models, because it suits the aim of this present study: i) it is user friendly and well suited to tracking energy demand and transformation in developing countries, ii) it is scenario-based and integrated with energy-environment model building tool, so that both energy demand and its environmental implications can be tracked within the same platform, iii) it includes a Technology and Environment Database (TED), which compiles technical characteristics and environmental impacts for range of energy technologies, including both advanced technologies for developed countries and conventional technologies often found in developing countries, iv) it is flexible with regards to data availability and has low initial data requirement which can

\footnotetext{
${ }^{3}$ For details about the LEAP software, see http://sei-us.org/software/leap
} 
be improved as detailed data becomes available for the study location and, v) it is free to use for developing country researchers and government agencies.

\subsection{Overall model description}

The LEAP model consists of three blocks of programmes: energy scenarios, aggregation, and the environmental database. The energy scenario block addresses the main components of an integrated energy analysis: energy demand analysis, energy conversion, resource assessment, emissions estimation, and the comparison of scenarios (Shin et al., 2005). LEAP is based on exogenous input of the main parameters. Scenarios are developed through exogenous assumptions of end-users' energy demand, which are influenced by factors like population growth, change in household size, increasing urbanisation and migration, as well as technological progress like improvements in energy efficiency and energy conversion. The energy demand of a particular sector is computed as the product of an activity level related to the level of energy service required (such as number of households, passenger-km of transportation, output of an industry, etc.) and an energy intensity, relating energy consumption to unit activity, with examples shown in equations 1 and 2 (Heaps, 2012). The choice of fuels, either for transportation or for the domestic sector, is based on exogenous input defined by the user in the demand module. In projecting future energy demand, LEAP considers growth in GDP, population and urbanisation.

$D_{b, s, t}=T A_{b, s, t} \times E I_{b, s, t}$

where $D$ is energy demand, $T A$ is total activity, $E I$ is energy intensity, $b$ is the branch, $s$ is scenario and $t$ is year (ranging from the base year to the end year).

\section{Transport fuel demand $_{t, y}=$ Stock $_{t, y} \times$ Mileage $_{t, y} \times$ Fuel economy $_{t, y}$}

where stock is the number of vehicles existing in a particular year, mileage is annual distance travelled per vehicle and fuel economy is fuel use per unit of vehicle distance travelled, $t$ is the type of vehicle and $y$ is the calendar year.

In the 'transformation' module, conversion and transportation (transmission and distribution) of energy forms, from the point of extraction of primary resources to the point of final consumption, are simulated with separate modules for the various types of energy conversion, like electricity generation, biofuel production, charcoal kilns, etc. Alternative scenarios are used to represent different future transformation configurations, reflecting different assumptions about policies and technologies.

In the case of electricity generation, for example, all available power plants, present and planned, are specified and the choice of which plants produce at a given time to meet the calculated electricity demand is made on the basis of a load duration curve, average availability factors and merit order, all specified exogenously. The latter may, for example, reflect the marginal production costs. Likewise technological progress is taken into consideration using exogenous conversion factors, and is a function of time. Finally, the resource analysis component is used to keep track of the availability of primary resources, including both fossil and renewable resources. 
The main output of the model is the evolution from the base year over the specified time period, of energy demand, the use of fossil and renewable energy resources and the level of emissions such as $\mathrm{CO}_{2}$. LEAP also provides options for a detailed analysis of economic implications of the built scenarios, but this falls outside of the scope of the present paper. A detailed cost analysis of bioenergy systems are the subject of a different paper by the authors.

\subsection{Base year modelling}

In order to project energy demand for the future, LEAP uses a base year, for which extensive data is available. The base year used for this study is 2010 - the last year in which a national population and housing census was conducted in Ghana. Energy demand projection is done from 2015 to 2030 . Historical data from the 2010 census and other relevant energy databases in the country were used in the 2010 base year. Details of historic aggregated energy indicators for the country are shown in Appendix 1.

The sectors taken into account for this modelling are: Households (or residential), Agriculture, Industry, Transport, Non-residential and Street Lighting. Each of these branches was further disaggregated into 'sub-branches'. Household sector is disaggregated into urban households and rural households. Urban households are further disaggregated into 'Metro Urban' and 'Other Urban', in line with energy data compilation from the 2010 population and housing census and a national energy survey conducted by the Energy Commission in the same year. Metro Urban households fall within the highest income group in the country and has the highest demand for energy in the country. Rural areas were subdivided into coastal, forest and savannah rural, defined by the various agro-ecological zones in the country. Due to the different agroecological zones, population dynamics and affluence of these rural areas, there are different patterns in fuel consumption. Based on historical data from the Ghana Statistical Services, the coastal and forest areas of the country tend to have higher population densities than the savannah areas. Details of the assumptions built into the model, including how Ghanaian communities are expected to shift from rural to urban, according to projections by the Ghana Statistical Services, is shown in Appendix 2.

In the 2010 base year, the 'transformation' module is mainly composed of energy technologies for electricity generation, oil refining and charcoal production, consistent with energy consumption pattern in the base year. In the bioenergy scenarios, the transformation module also includes technologies for the production of biodiesel, ethanol and biogas. Data on electricity generation plants, oil refinery and charcoal production methods for the base year were obtained from the Energy Commission (Energy Commission, 2013). The 'resource' module builds energy resource requirements based on data input in the transformation module. In the 2010 base year, resources include crude oil for the refinery, various fuels for electricity generation and wood for charcoal production. The resource module provides energy supply options and their implications for carbon emissions.

\subsection{Scenario analysis}

To project energy demand from the 2010 base year, three energy scenarios were developed a reference (or business-as-usual) scenario and moderate and high bioenergy scenarios. The reference scenario projects energy demand and supply options using a business-as-usual approach. The moderate and high bioenergy scenarios were characterised primarily by increasingly aggressive infusion of bioenergy into the energy mix. 


\subsubsection{Reference scenario}

The reference scenario examines how Ghana's energy system might evolve up to 2030 in the absence of significant new policies for bioenergy. The demand projection for energy is driven mainly by projected GDP and population growth. Based on the growth projections, it is expected that the number of households in Ghana would increase from 5.5 million in 2010 to about 8.4 million in 2030 (Ghana Statistical Services, 2012). Energy demand for urban areas differs from rural areas in types of fuel and amount consumed. Urban communities are defined by the Ghana Statistical Service as communities with population above 5000. By this definition, Ghana had more than half of households (56\%) living in urban areas in 2010. In 2030 , it is expected that $65 \%$ of the projected 8.4 million households would be urban. This could potentially increase energy consumption and also serve as a driver for an increased use of modern fuels, such as electricity for lighting and Liquefied Petroleum Gas (LPG) for cooking. With regards to transportation, passenger- $\mathrm{km}$ is expected to grow at an annual rate of $6 \%$. Road transportation is currently the dominant transport mode. However, the share of road transportation is projected in the model to decrease from $95 \%$ in 2010 to about $80 \%$ in 2030 with rail and air transport accounting for the remaining $20 \%$.

In the reference scenario, electricity generation is based on a 'Generation Master Plan Study for Ghana', a study by Tractebel Engineering for the Ghana Grid Company Limited (GRIDCO, 2011). The study developed a 15 year electricity generation plan which is aimed at guiding investment in generation for both the public and private sector. Oil refining capacity is based on the capacity of the country's only oil refinery. Charcoal production in the reference scenario uses existing methods of producing charcoal in Ghana, predominantly the earth mound kiln. Going forward, it is assumed that improved charcoal kilns would be introduced gradually and account for $20 \%$ of charcoal output by 2030 .

\subsubsection{Environmental effect / GHG Emissions}

GHG emissions for the reference scenario were estimated for energy demand and also for energy transformation or conversion. Estimation for energy demand captures all non-biogenic emissions. Non-biogenic emissions are those emissions from fuels of non-biological origin and include emissions from fossil fuels used in transportation and other sectors such as industry and agriculture. The analysis uses a straightforward accounting methodology in which emissions of different pollutants are calculated as the product of fuel combustion and an emission factor, following the IPCC methodology. Estimation for energy transformation or conversion captures non-biogenic emissions from the use of fossil fuels to generate electricity, using the generation fuel sources from individual generation plants. Biogenic emissions, which are emissions emanating from fuels of biological origin (e.g. burning of firewood and charcoal) have not been computed in this study. The issue of equating biogenic emissions to fossil-fuel emissions is one that is still very much debated (Gunn et al., 2012). Indeed, this study relies on the IPCC methodology for computing emissions (IPCC, 2006) which does not attribute biogenic emissions to the energy sector.

\subsubsection{Bioenergy scenarios}

Next to the reference scenario are two bioenergy scenarios, a moderate bioenergy scenario and a high bioenergy scenario. These two scenarios assume bioenergy infusion into Ghana's energy mix. A number of technologies could be deployed which could utilize biomass as feedstock for the production of desired energy forms for the country. Table 1 summarizes the technology options that could allow the substitution of bioenergy fuels for fossil fuels. Other advanced 
technologies such as pyrolysis which are still being perfected for commercial applications (Jahirul et al., 2012) are possible technological options for consideration in the future.

The high bioenergy scenario is an increased use of bioenergy compared to the moderate bioenergy scenario. In the moderate bioenergy scenario, it is assumed that $0.1 \%$ of households in non-metro urban households would switch to biogas as one of their cooking fuels, rising to $2 \%$ by 2030 . A higher number of households in rural communities would be expected to switch to biogas, reaching $10 \%$ by 2030 . With regards to transport, an estimated $10 \%$ of road passenger transport would use biodiesel and ethanol by 2030 while $10 \%$ of rail transport and road freight transport is to rely on biodiesel. Electricity from biomass resources is assumed to be generated from municipal solid waste, wood waste, oil palm waste and cocoa waste. The share of improved charcoal carbonisation technologies would increase in the bioenergy scenarios, contributing $35 \%$ and $60 \%$ respectively to charcoal output in the moderate and high bioenergy scenarios. There would also be a gradual uptake of improved cookstoves, beginning with just $0.1 \%$ national penetration in 2015 to $5 \%$ in the moderate bioenergy scenario and $10 \%$ in the high bioenergy scenario. Other assumptions that make up the bioenergy scenarios are summarised in Table 2.

Table 1: Possible technology options that allow fossil fuels to be substituted with biomass based fuels

\begin{tabular}{|c|c|c|c|}
\hline Feedstock & Energy production & Energy conversion & Substituted fuel \\
\hline \multicolumn{4}{|l|}{ Electricity generation* } \\
\hline Municipal solid waste & Land fill gas capture & $\begin{array}{l}\text { Gas turbine/ Internal } \\
\text { Combustion Engine } \\
\text { (ICE) }\end{array}$ & Natural gas/crude oil \\
\hline Wood waste & $\begin{array}{l}\text { Combustion / } \\
\text { Gasification }\end{array}$ & $\begin{array}{l}\text { Steam turbine/ Gas } \\
\text { turbine }\end{array}$ & Natural gas/crude oil \\
\hline Oil palm waste & $\begin{array}{l}\text { Combustion / } \\
\text { Gasification }\end{array}$ & $\begin{array}{l}\text { Steam turbine/ Gas } \\
\text { turbine }\end{array}$ & Natural gas/crude oil \\
\hline \multicolumn{4}{|l|}{ Transportation } \\
\hline $\begin{array}{l}\text { Crop residues (cereal waste, } \\
\text { cassava waste, etc.) }\end{array}$ & Ethanol fermentation & ICE & Gasoline \\
\hline $\begin{array}{l}\text { Energy crops (cassava, } \\
\text { sugarcane, etc.) }\end{array}$ & Ethanol fermentation & ICE & Gasoline \\
\hline $\begin{array}{l}\text { Energy crops (jatropha, } \\
\text { sunflower, etc.) }\end{array}$ & Biodiesel refinery & ICE & Diesel \\
\hline \multicolumn{4}{|l|}{ Cooking fuel } \\
\hline $\begin{array}{l}\text { Animal manure and crop } \\
\text { residue }\end{array}$ & Biogas digester & Biogas stoves & Firewood and charcoal \\
\hline
\end{tabular}

*Some wood and oil palm processing companies already produce electricity from residues using combustion technology. The technology is already feasible in the country but some scaling up may be needed to increase generation capacity. 
Table 2: Highlight of assumptions in the different scenarios

\begin{tabular}{|c|c|c|c|c|}
\hline Feedstock & $\begin{array}{l}\text { Base year } \\
(2010)\end{array}$ & $\begin{array}{l}\text { Reference } \\
\text { Scenario }\end{array}$ & $\begin{array}{l}\text { Moderate } \\
\text { bioenergy }\end{array}$ & High bioenergy \\
\hline \multicolumn{5}{|l|}{ Electricity generation } \\
\hline $\begin{array}{l}\text { Municipal solid waste } \\
\text { Wood waste } \\
\text { Oil palm waste } \\
\text { Cocoa }\end{array}$ & $\begin{array}{l}\text { Insignificant } \\
\text { contribution - } \\
\text { not counted in } \\
\text { national statistics }\end{array}$ & $\begin{array}{l}\text { Same as in } \\
\text { current account }\end{array}$ & $\begin{array}{l}\text { Combined } 1.4 \% \text { of } \\
\text { electricity } \\
\text { generated by } 2030\end{array}$ & $\begin{array}{l}\text { Combined } 4.0 \% \\
\text { of electricity } \\
\text { generated by } \\
2030\end{array}$ \\
\hline \multicolumn{5}{|l|}{ Cocoa } \\
\hline \multicolumn{5}{|l|}{ Transportation } \\
\hline $\begin{array}{l}\text { Crop residues (for } \\
\text { ethanol production) }\end{array}$ & $\begin{array}{l}\text { No commercial } \\
\text { production of }\end{array}$ & $\begin{array}{l}\text { Road passenger } \\
\text { transport }(0 \%)\end{array}$ & $\begin{array}{l}\text { Road passenger } \\
\text { transport }(10 \%)\end{array}$ & $\begin{array}{l}\text { Road passenger } \\
\text { transport }(20 \%)\end{array}$ \\
\hline $\begin{array}{l}\text { Energy crops } \\
\text { (jatropha, sunflower, } \\
\text { etc.) }\end{array}$ & $\begin{array}{l}\text { biofuels for } \\
\text { transportation in } \\
\text { the country. }\end{array}$ & $\begin{array}{l}\text { Road } \\
\text { passenger } \\
\text { transport } \\
(0 \%) \text {; rail } \\
\text { transport } \\
(0 \%) \text {; road } \\
\text { freight } \\
\text { transport }(0 \%)\end{array}$ & $\begin{array}{l}\text { Road passenger } \\
\text { transport }(10 \%) \text {; } \\
\text { rail transport } \\
(10 \%) \text {; road } \\
\text { freight transport } \\
(10 \%)\end{array}$ & $\begin{array}{l}\text { Road } \\
\text { passenger } \\
\text { transport } \\
(20 \%) ; \text { rail } \\
\text { transport } \\
(20 \%) ; \text { road } \\
\text { freight } \\
\text { transport } \\
(20 \%)\end{array}$ \\
\hline \multicolumn{5}{|l|}{ Cooking fuel } \\
\hline $\begin{array}{l}\text { Animal manure and } \\
\text { crop residue }\end{array}$ & $\begin{array}{l}\text { Few small } \\
\text { scale biogas } \\
\text { plants exist. } \\
\text { Not counted in } \\
\text { national } \\
\text { statistics. }\end{array}$ & $\begin{array}{l}\text { Non-metro } \\
\text { urban HH } \\
(0 \%) ; \text { coastal } \\
\text { rural HH }(0 \%) \\
\text { all other rural } \\
\text { HH }(0 \%)\end{array}$ & $\begin{array}{l}\text { Non-metro urban } \\
\text { HH }(2 \%) \text {; rural } \\
\text { HH }(10 \%)\end{array}$ & $\begin{array}{l}\text { Non-metro } \\
\text { urban HH } \\
(5 \%) \text {; rural } \\
\text { HH }(20 \%)\end{array}$ \\
\hline
\end{tabular}

HH-households

\section{RESULTS AND DISCUSSION}

\subsection{Reference scenario}

\subsubsection{Energy demand}

The projected final energy demand of Ghana in the reference scenario is summarised in Figure 1. The country's total final energy demand would double between 2015 and 2030, an increase from 329 PJ in 2015 to 644 PJ. Diesel, electricity, woodfuel and gasoline, would dominate fuel demand in the year 2030. Diesel consumption would more than double in the planning period, rising from $89 \mathrm{PJ}$ in 2015 to approximately $203 \mathrm{PJ}$ in 2030. The increased diesel demand is attributed to increases in the transportation, industry and agriculture sectors. Growth in electricity demand would be boosted by increased population and urbanisation. Wood and charcoal would be needed primarily for residential cooking and heating, with the greater part of wood demand coming from rural communities. The major energy demand sectors are transportation, industry and residential sector. Minor demand sectors include street lighting, agriculture and non-residential sector. The transportation sector is expected to become the highest consumer of energy by 2030, followed by the residential sector. In 2030, the 
transportation sector would account for $50 \%$ of total energy demand in the reference scenario. The residential sector would account for $23 \%$ of demand. Together, the two sectors account for three-quarters of energy demand.

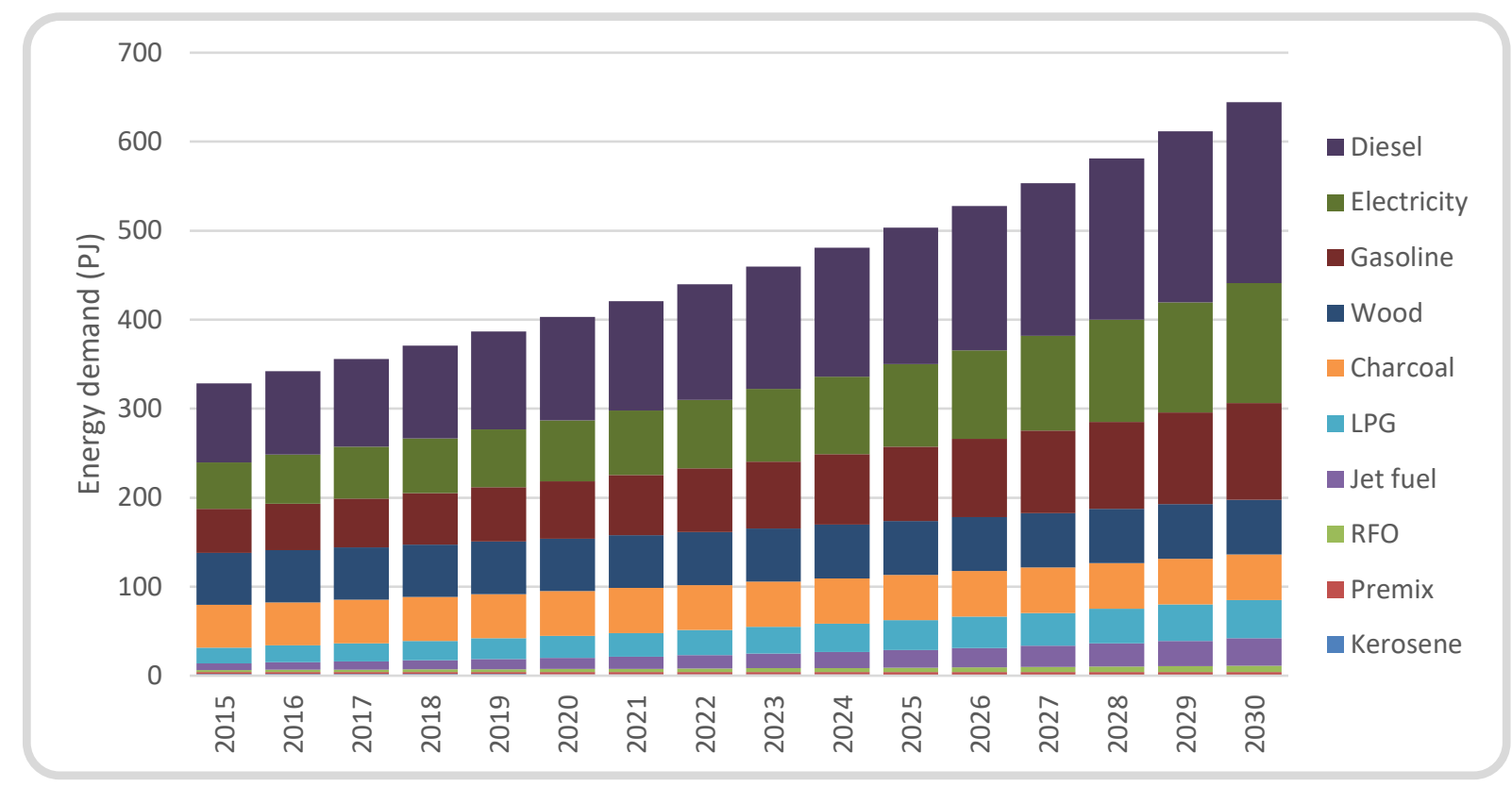

Figure 1: Projected energy demand by fuel type

Installed electricity generation capacity is expected to increase from about 3,500 MW in 2015 to nearly 6,000 MW in 2030, which is close to a doubling of generation capacity within the 15 year period. Electricity supply in the reference scenario is assumed to be produced by thermal, large hydro, and renewables comprising solar, wind and small hydro. Currently, the fuels for thermal generation are Light Crude Oil (LCO) and natural gas. However, LCO is to be phased out by the end of 2014 and natural gas used entirely to run thermal plants as outlined in the national electricity generation master plan (GRIDCO, 2011). Natural gas is presently sourced from two sources: the West Africa Gas Pipeline ${ }^{4}$ which has proven unreliable, with erratic supply, and the country's own gas processing plant that began operation in December 2014. Figure 2 shows projected electricity generation by fuel source from 2015 to 2030 . The thermal share of electricity generation capacity would rise to about $63 \%$ in 2030 , from $46 \%$ in 2012 . Electricity from renewables would contribute $10 \%$ to total electricity generation capacity. In the reference scenario, biomass would not contribute any capacity to electricity generation.

\footnotetext{
${ }^{4}$ The West Africa Gas Pipeline is a natural gas pipeline that supplies gas from Nigeria to Benin, Togo and Ghana. The pipeline is owned by the West African Pipeline Company (WAGPCo), a consortium of 6 partners.
} 


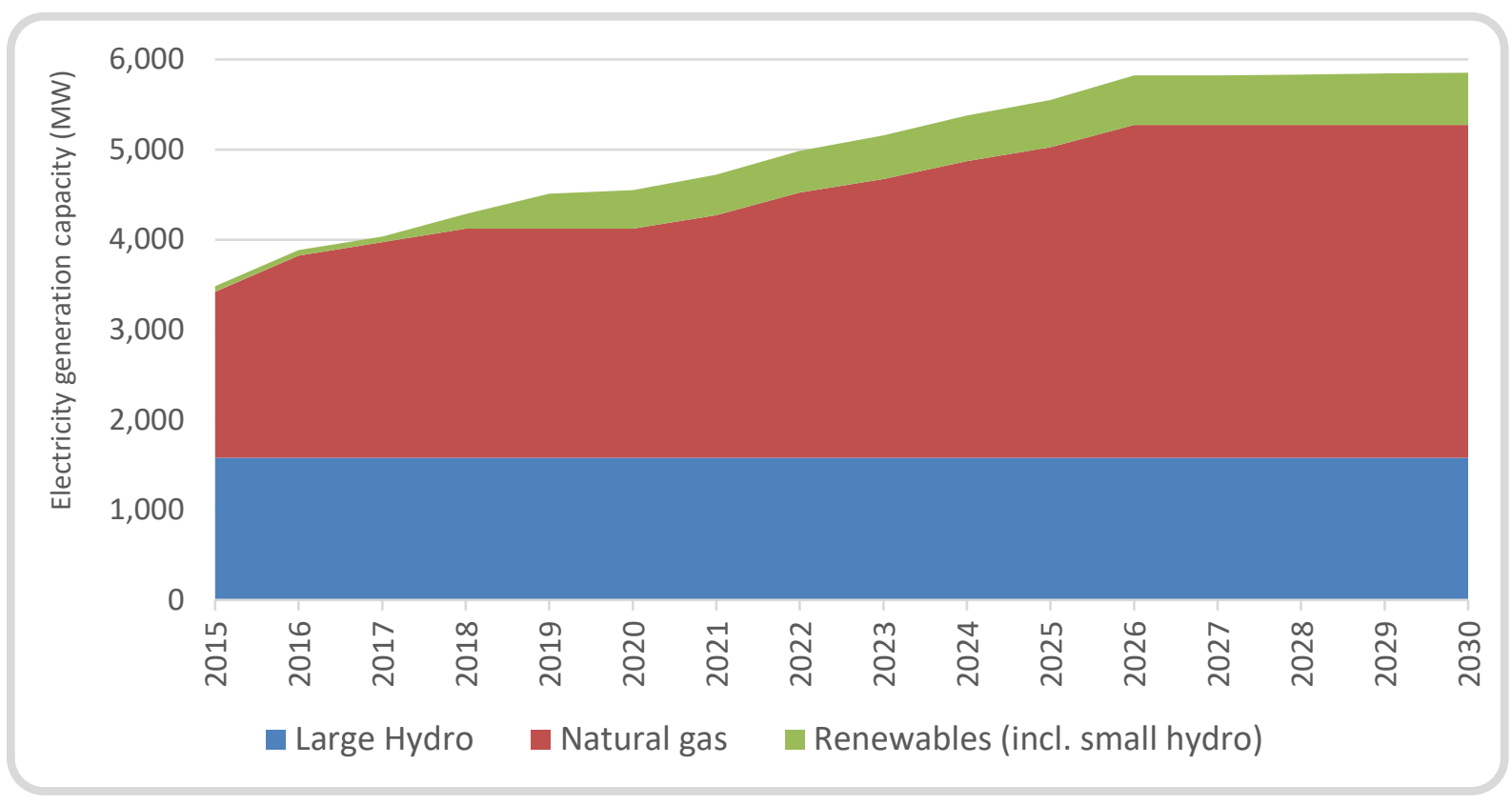

Figure 2: Projected electricity generation by source

Source: Modified from GRIDCo, 2011

\subsubsection{Greenhouse gas emissions}

In the LEAP model, emissions from energy are subdivided into two components. The first component are those emissions that are accounted for at the point of use (such as in cars) and are referred to as 'demand side emissions' in this study. The second component of emissions is accounted for at the point of transformation (such as electricity generation) and will be referred to as 'transformation emissions' in this study. Figure 3 shows the GHG emissions ${ }^{5}$ arising from demand and transformation. Demand side emissions would more than double between 2015 and 2030, rising from about $12 \mathrm{MtCO}_{2} \mathrm{e}$ in 2015 to more than $28 \mathrm{MtCO}_{2} \mathrm{e}$ by 2030. Gasoline and diesel comprise more than $80 \%$ of demand side emissions. The high contribution from diesel and gasoline is the result of substantial increase in transportation.

Transformation emissions have their source in electricity generation. Transformation emissions would more than triple between 2015 and 2030. From 3.8 $\mathrm{MtCO}_{2} \mathrm{e}$ in 2015, GHG emissions from transformation are projected to exceed $12.45 \mathrm{MtCO}_{2} \mathrm{e}$ by 2030 . Transformation emissions would rise constantly due to an anticipated increase in electricity generation capacity. Electricity generation is projected to increase from $20,000 \mathrm{GWh}$ in 2015 to $43,000 \mathrm{GWh}$ in 2030 , out of which about $80 \%$ would be delivered by thermal sources ${ }^{6}$ compared to an estimated $62 \%$ in 2015 . This is expected to increase the national electricity grid's carbon intensity from $0.18 \mathrm{tCO}_{2} \mathrm{e}$ per MWh in 2015 to $0.28 \mathrm{tCO}_{2} \mathrm{e}$ per $\mathrm{MWh}$ in 2030.

The net GHG emission from energy consumption is obtained by summing the emissions from final energy demand and emissions from energy transformation. The final emission in 2030, $40.8 \mathrm{MtCO}_{2} \mathrm{e}$, is more than twice the emission in 2015 of $16 \mathrm{MtCO}_{2} \mathrm{e}$. Throughout the planning period, emissions from energy demand would account for between $69-76 \%$ of the total emissions per year. Two very important indicators, with regards to emissions, are emissions

\footnotetext{
5 'one hundred year' global warming potential

${ }^{6}$ It should be noted that even though thermal generation capacity will reach $63 \%$ of total capacity by 2030 , actual generation from thermal sources is higher.
} 
per capita and emissions per GDP. Based on the projected population growth in the reference scenario, emissions per capita ${ }^{7}$ would double, increasing from $0.6 \mathrm{tCO}_{2} \mathrm{e}$ in 2015 to $1.2 \mathrm{tCO}_{2} \mathrm{e}$ in 2030. Emissions per GDP would decrease marginally, from $0.303 \mathrm{tCO}_{2}$ e per 1,000 US\$ in 2015 to $0.296 \mathrm{tCO}_{2} \mathrm{e}$ per 1,000 US\$ in 2030.

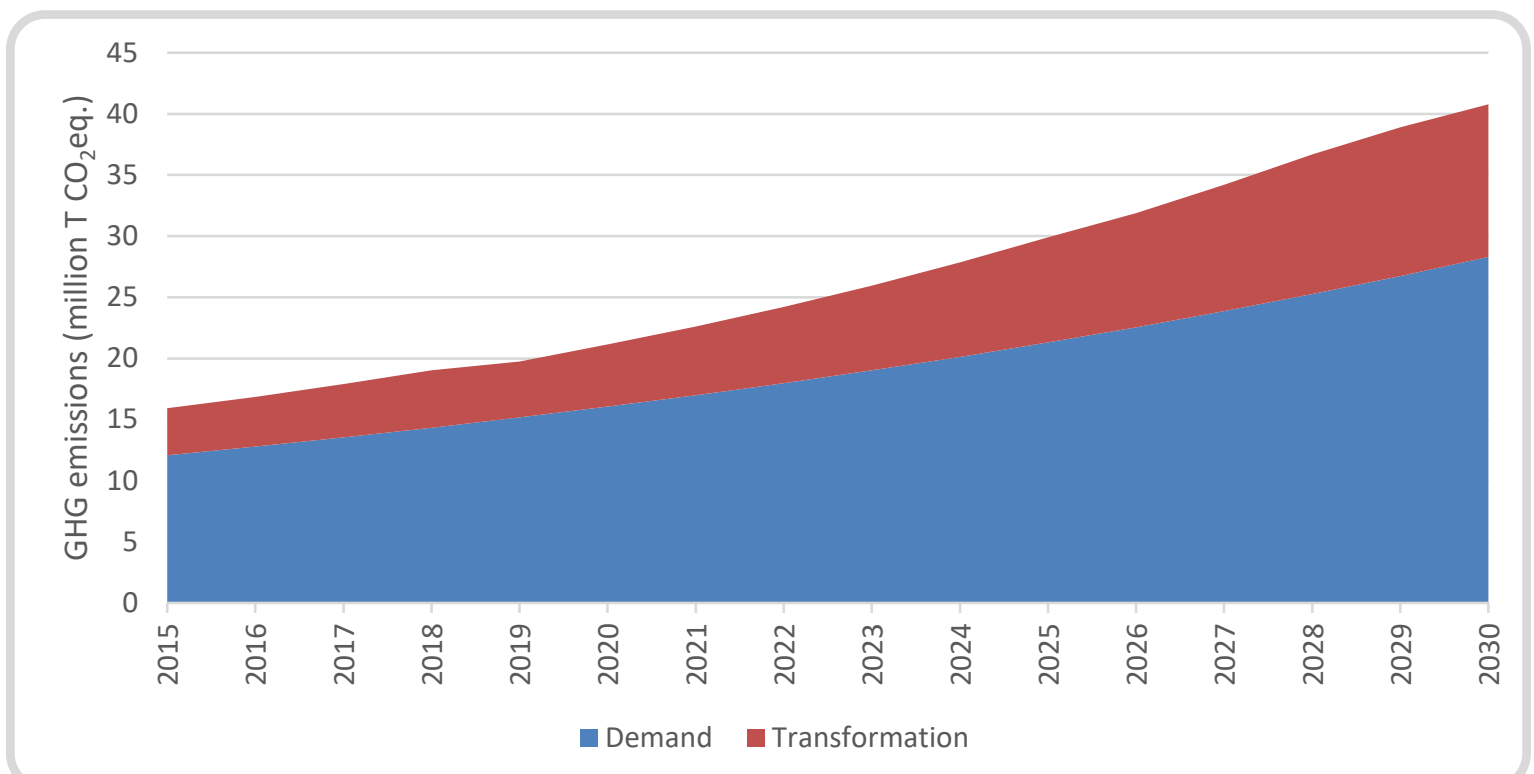

Figure 3: Projected net GHG emissions from energy conversion and consumption

\subsection{Bioenergy scenarios}

\subsubsection{Electricity generation}

In the reference scenario, electricity generation was assumed to follow a master plan that has been developed for the country. Even though the master plan considered solar, wind and minihydro in the generation mix, it did not make any provision for electricity generation from biomass sources. The bioenergy scenario therefore sought to analyse the potential for biomass resources to contribute to electricity generation between 2015 and 2030.

In the bioenergy scenarios, biomass electricity generation sources are municipal solid waste (MSW), wood waste, oil palm waste and cocoa waste. Potential technologies to generate electricity from MSW include combustion, gas from anaerobic digestion and landfill gas capture. This model assumed that electricity generation from MSW would rely on landfill gas technology and the other feedstock types would undergo combustion. One of the advantages of electricity generation from biomass resources is that distributed generation technologies can be easily deployed and power produced at agro-industrial plants and rural communities where feedstock is generated and in abundance. Power produced could be used within the site/community where it is produced or it could be fed into the grid as desired.

A summary of electricity generation from biomass sources is presented in Table 3 . In the moderate bioenergy scenario, total capacity of electricity generation from biomass could start from $50 \mathrm{MW}$ in 2015 and rise to about $65 \mathrm{MW}$ by 2030. This is expected to contribute about $2.0 \%$ of generated electricity by 2015 and $1.4 \%$ by 2030 . In the high bioenergy scenario,

\footnotetext{
${ }^{7}$ These are energy emissions alone. They do not include other sectors such as waste disposal, agriculture, forestry, land use and land use change.
} 
installed electricity generation capacity from biomass resources could amount to $155 \mathrm{MW}$ and rise to $200 \mathrm{MW}$ by 2030 . Electricity from biomass resources in the high bioenergy scenario would contribute $4.0 \%$ to total electricity generated in 2030 . In the high bioenergy scenario, electricity from all renewables (including from biomass) would contribute about $9 \%$ to total generation by 2030 , compared to $6.4 \%$ in the moderate bioenergy scenario.

Table 3: Electricity generation in bioenergy scenarios

\begin{tabular}{lcccc}
\hline \multirow{2}{*}{ Power from bioenergy } & \multicolumn{2}{c}{ Moderate bioenergy } & \multicolumn{2}{c}{ High bioenergy } \\
\cline { 2 - 5 } & $\mathbf{2 0 1 5}$ & $\mathbf{2 0 3 0}$ & $\mathbf{2 0 1 5}$ & $\mathbf{2 0 3 0}$ \\
\hline Installed Capacity (MW) & 50 & 65 & 155 & 200 \\
$\begin{array}{l}\text { Electricity generated (GWh) } \\
\begin{array}{l}\text { Biomass as percentage of total } \\
\text { electricity }\end{array}\end{array}$ & 412 & 590 & 1186 & 1769 \\
$\begin{array}{l}\text { Percentage contribution from } \\
\text { other renewables (excl. large } \\
\text { hydro) }\end{array}$ & $0.5 \%$ & $5.0 \%$ & $0.5 \%$ & $5.0 \%$ \\
\hline
\end{tabular}

\subsubsection{Transportation sector}

Ethanol and biodiesel are the principal biomass sourced fuels used in the transportation sector. Only ground transportation, i.e. road and rail, was considered for bioenergy use in the bioenergy scenarios. In the moderate bioenergy scenario, biodiesel would contribute $0.3 \%$ of transportation energy requirement in 2015 , rising to $5.4 \%$ in 2030 as summarised in Table 4. Demand for ethanol would amount to $0.2 \%$ of transportation energy in 2015 and rise to $4.8 \%$ in 2030. In the high bioenergy scenario, total biofuels demand would increase from $1.1 \%$ in 2015 to $21 \%$ in 2030 . The high bioenergy scenario is therefore in consonance with a draft bioenergy document (Energy Commission, 2010) which called for a $10 \%$ biofuels in transportation fuels by 2020 and $20 \%$ by 2030 .

Table 4: Percentage of road transport fuels in bioenergy scenarios, by energy content

\begin{tabular}{lcccc}
\hline \multirow{2}{*}{ Transport fuel type } & \multicolumn{2}{c}{ Moderate bioenergy } & \multicolumn{2}{c}{ High bioenergy } \\
\cline { 2 - 5 } & $\mathbf{2 0 1 5}$ & $\mathbf{2 0 3 0}$ & $\mathbf{2 0 1 5}$ & $\mathbf{2 0 3 0}$ \\
\hline Biodiesel & $0.3 \%$ & $5.4 \%$ & $0.7 \%$ & $11.2 \%$ \\
Diesel & $62.4 \%$ & $58.2 \%$ & $62.2 \%$ & $53.2 \%$ \\
Ethanol & $0.2 \%$ & $4.8 \%$ & $0.4 \%$ & $9.9 \%$ \\
Gasoline & $37.0 \%$ & $31.5 \%$ & $36.8 \%$ & $25.8 \%$ \\
Total biofuels & $0.5 \%$ & $10.2 \%$ & $1.1 \%$ & $21.0 \%$ \\
\hline
\end{tabular}

In terms of actual biofuel requirements, Table 5 gives an indication of the biodiesel and ethanol required to meet the percentages shown in Table 4 . In the moderate bioenergy scenario, about $0.44 \mathrm{PJ}$ of biofuels would be required in 2015, increasing to over $15.53 \mathrm{PJ}$ in 2030. In the high bioenergy scenario, close to $0.88 \mathrm{PJ}$ of biofuels would be needed in 2015, and increase to over 
$31 \mathrm{PJ}$ in 2030. In 2020, about $12.77 \mathrm{PJ}$ (or approximately 480 million litres) of biofuels are needed in the transportation sector for the high bioenergy scenario. This is more than the 336 million litres estimated by Antwi et al. (2010) to meet 2020 requirements for biofuels in order to meet the requirements of the draft bioenergy policy.

Table 5: Biofuels requirement in bioenergy scenarios

\begin{tabular}{lcccccc}
\hline \multirow{2}{*}{ Bioenergy } & \multicolumn{3}{c}{ Moderate bioenergy } & \multicolumn{3}{c}{ High bioenergy } \\
\cline { 2 - 7 } Biodiesel (PJ) & $\mathbf{2 0 1 5}$ & $\mathbf{2 0 2 0}$ & $\mathbf{2 0 3 0}$ & $\mathbf{2 0 1 5}$ & $\mathbf{2 0 2 0}$ & $\mathbf{2 0 3 0}$ \\
\cline { 2 - 7 } Ethanol (PJ) & 0.44 & 3.44 & 15.53 & 0.88 & 6.88 & 31.06 \\
Total biofuels (PJ) & 0.27 & 2.94 & 13.73 & 0.54 & 5.88 & 27.46 \\
\hline
\end{tabular}

\subsubsection{Residential sector}

The policy of the Government of Ghana is to have $50 \%$ of households in the country using LPG as cooking fuel by 2020 , from about $18.2 \%$ in 2010 . While this is ambitious, an analysis by Mensah et al. (2014) has shown that rural dwellers may be left out of the transition to LPG for a long time yet. This is because the LPG marketing model in the country, where consumers must convey LPG cylinders to the nearest LPG retail stations to have them filled, has made it difficult for rural communities to access LPG. This difficulty is attributed to the fact that LPG retail stations are located far from most rural communities, with poor transportation infrastructure. For such rural communities, the short to medium term solution is the provision of other more accessible modern cooking fuels. Efforts to enable rural communities switch to modern cooking fuels is one of the central themes of Ghana's Renewable Energy Act (Ministry of Energy, 2011) which aims to promote and support the increased use of improved biomass technologies through legislation, fiscal incentives and attractive packages. In the short to medium term, bio-digesters are one of the appropriate rural improved biomass technology options, producing methane as for cooking and heating. The switch to methane gas is intended to reduce woodfuel use intensity in the Ghanaian economy. Under the Sustainable Energy for All (SE4ALL) programme, the Government of Ghana has also targeted improved cookstoves as one of the mediums to reduce woodfuel usage. Improved cookstoves marketed in Ghana are the residential charcoal types and it is expected that, going forward, the bulk of these stoves would continue to be the residential improved cookstoves. Since charcoal consumption is higher in urban areas and also because of the cookstove marketing models adopted, penetration of improved cookstoves is expected to be higher in urban communities than in rural communities.

In the reference scenario, demand for woodfuel is about $374 \mathrm{PJ}$ in 2015 , rising to $386 \mathrm{PJ}$ in 2030. Switching to biogas in the alternative scenarios would enable a replacement of some woodfuel with biogas. In the moderate bioenergy scenario, biogas would displace $0.10 \mathrm{PJ}$ of woodfuel in 2015, increasing to 6.21 PJ in 2030. In the high bioenergy scenario, displacement of woodfuel by biogas would start at $0.55 \mathrm{PJ}$ in 2015 and reach $13.15 \mathrm{PJ}$ in 2030. In addition to biogas, the increased use of improved charcoal carbonisation technologies and improved cookstoves in the alternative scenarios would further reduce the demand for woodfuel. In the moderate bioenergy scenario, improved carbonisation technologies would contribute $35 \%$ of total charcoal production by 2030 , compared to just $20 \%$ in the reference scenario. In the high bioenergy scenario, the fraction of total charcoal produced by improved technologies reaches 
$60 \%$. The resultant displacement of woodfuel, from a combined biogas demand, increased use of improved cookstoves, and use of improved carbonisation technologies, is summarised in Figure 4. In the moderate bioenergy scenario, about 71 PJ of woodfuel would be saved in 2030, rising to $138 \mathrm{PJ}$ in the high bioenergy scenario. This is in line with the country's strategic national energy plan of 2006 in which the Ghana Energy Commission is hoping for a reduction in woodfuel intensity in Ghana's energy sector. Achieving this feat would require a lot of investment, especially in the rural biogas sector. It would also be prudent to introduce improved carbonisation technologies and to make appropriate laws that require a certain percentage of charcoal is produced using these improved technologies, especially for large-scale and frequent charcoal producers. The Forestry Commission and the Environmental Protection Agency could be empowered to enforce these laws and lead the effort towards reduced woodfuel use in the energy sector.

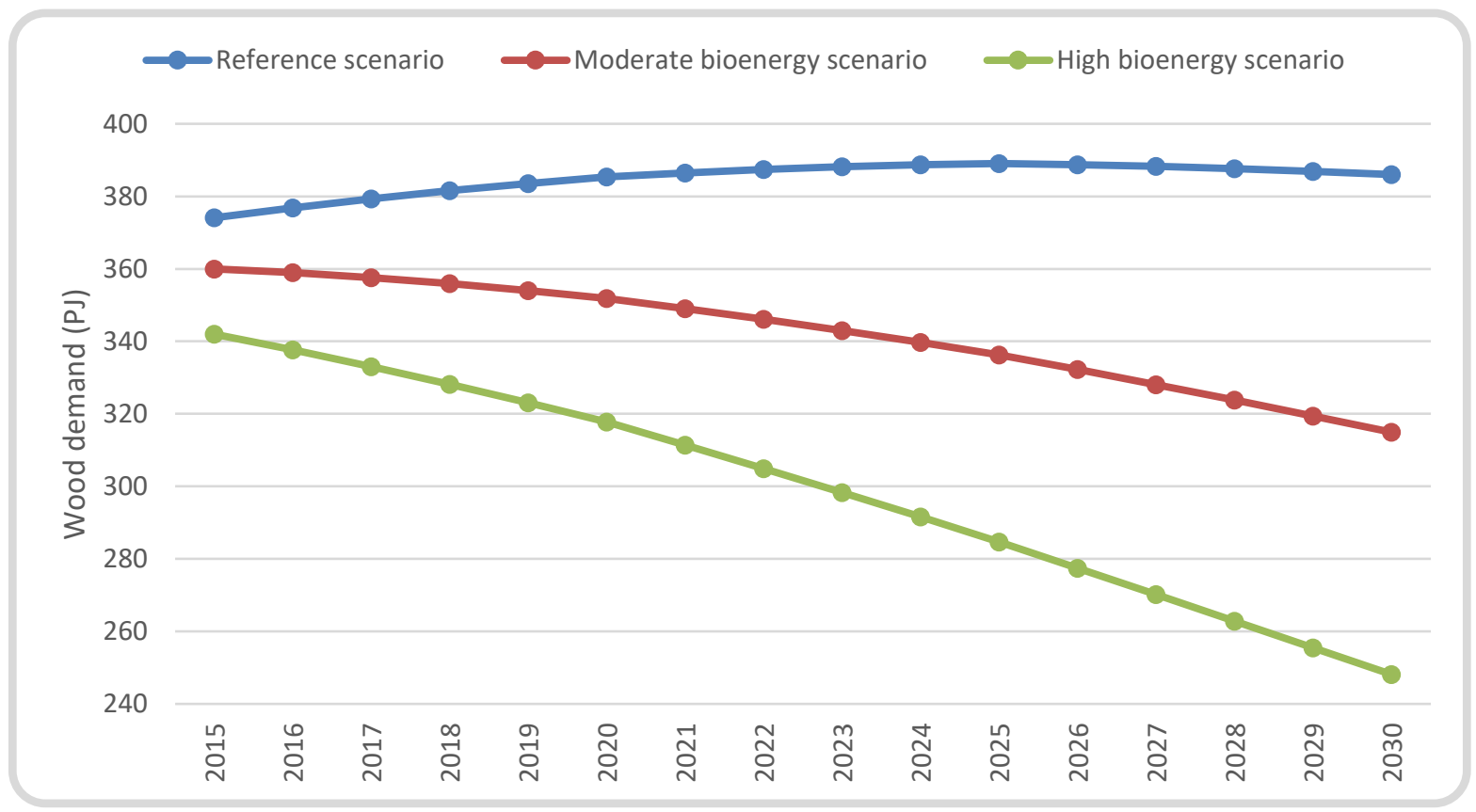

Figure 4: Woodfuel demand in reference, moderate and high bioenergy scenarios

\subsection{Resource requirement in bioenergy scenario}

As much as practicable, bioenergy types discussed in this study are assumed to be produced from lignocellulosic biomass sourced from within the country. Table 6 presents details of resource availability and their contribution towards the production of the different energy carriers. Resource projection to 2030 was done through regression analysis, using growth rate of each biomass type over the past decade. For resource types with growth rate of more than $3 \%$ (which includes cassava of 5.1\% growth rate and maize of $6 \%$ and rice of $9.3 \%$ ), this growth rate was used to project future biomass availability up to year 2020, then three-quarters of the growth rate was used to project growth from 2020 to 2025, and finally, half of the growth rate was used to project growth from 2025 to 2030 . Where growth rate was less than $3 \%$ (and these include groundnut of $2.2 \%$, millet of $2.7 \%$ and oil palm of $1.1 \%$ ), the growth rate was maintained up to 2030 . The projections were meant to be as conservative as possible rather than being overly optimistic and were guided by the fact that agricultural lands are finite resources and production expansion would not be possible perpetually. The only way to boost production without using much land is to increase crop yields, something that has been difficult 
to achieve in the past due to poor rainfall and minimal use of soil additives in most agricultural communities in Ghana.

Biogas for residential cooking is assumed to be produced from livestock manure in the first instance. Depending on technology improvement, crop residues could supplement livestock manure in the production of biogas. Presently, research is ongoing on the co-digestion of livestock manure and crop residues with some success reported (see for example Chandra $e t$ al., 2012; Muhammad Nasir et al., 2012; Brown et al., 2012; Liew et al., 2012; Cui et al., 2011; Li et al., 2011; Wu et al., 2010) and it is hoped that the technology could be commercially available in the not too distant future. In the year 2015, close to $12 \mathrm{PJ}$ of livestock manure could be available, rising to more than $21 \mathrm{PJ}$ by 2030 . This would be enough to meet resource requirement for biogas in the high bioenergy scenario by 2030, of 13.15 PJ. If the projected future resource becomes available, there might be no need to co-digest manure with crop residues, except when co-digestion could increase manure yields, a situation that is dependent on ongoing research.

Table 6: Assumptions of biomass resource requirement in the bioenergy scenarios

\begin{tabular}{|c|c|c|c|c|c|c|}
\hline \multirow[t]{2}{*}{ Feedstock } & \multicolumn{2}{|c|}{ Resource potential (PJ) } & \multicolumn{2}{|c|}{ Moderate bioenergy (PJ) } & \multicolumn{2}{|c|}{ High bioenergy $(\mathbf{P J})$} \\
\hline & 2015 & 2030 & 2015 & 2030 & 2015 & 2030 \\
\hline \multicolumn{7}{|l|}{ Electricity generation } \\
\hline Municipal solid waste & 44.2 & 70.1 & 9.3 & 14.3 & 27.9 & 44.7 \\
\hline Wood waste & 4.8 & 4.8 & 1.2 & 1.2 & 3.6 & 3.6 \\
\hline Oil palm waste & 12.7 & 14.9 & 3.2 & 4.1 & 9.5 & 12.7 \\
\hline Cocoa waste & 27.4 & 39.2 & 6.9 & 10.6 & 20.6 & 33.0 \\
\hline \multicolumn{7}{|l|}{ Transportation } \\
\hline $\begin{array}{l}\text { Ethanol (cereal waste, } \\
\text { cassava waste, other crop } \\
\text { wastes) }\end{array}$ & 306.6 & 579.7 & 0.8 & 39.2 & 1.6 & 78.5 \\
\hline $\begin{array}{l}\text { Biodiesel (sunflower and } \\
\text { jatropha)* }\end{array}$ & NA & NA & 0.4 & 15.5 & 0.9 & 31.1 \\
\hline \multicolumn{7}{|l|}{ Cooking fuels } \\
\hline Animal manure & 11.6 & 21.4 & 0.1 & 6.2 & 0.6 & 13.2 \\
\hline
\end{tabular}

*Figures shown indicate actual biodiesel demand

With regard to transportation fuels, it is assumed that a combination of cereal waste, cassava waste and the other waste types not considered for electricity are available for fermentation, subject to technology availability. As shown in Table 6, the resources required for ethanol production in the high bioenergy scenario by 2030 are a lot less, compared to how much could be available. Producing ethanol from lignocellulosic feedstock avoids the 'food vs fuel' challenge which has become a contentious issue in the global discourse on biofuels. As noted by Azad et al. (2015), second generation biofuels 'can overcome the social, economic and environmental challenges without hampering our food cost and creating pressure on land use because it is non-edible, biodegradable and can grow on marginal land'. 
However, notwithstanding the fact that the social and environmental gains of producing biofuels from lignocellulosic biomass are many, it is unclear to what extent second generation biofuel technologies can compete favourably with first generation technologies with respect to costs. Second generation technologies are known to have higher costs as alluded to by a number of studies (Meihui et al., 2015; Ramamurthi et al., 2014; Pourhashem et al., 2013; Manatt et al., 2013; Haarlemmer et al., 2012; Stephen et al., 2012).

This implies that more research is needed to reduce costs in order to make second generation biofuels attractive for upscaling in developing countries such as Ghana. Higher costs would not encourage second generation technologies adoption and this would have consequences for land resource use. As an example, if all of the ethanol needed in the high bioenergy scenario were to be produced from first generation technologies using conventional energy crops, this would entail the use of over 583,000 ha of land by 2030, or approximately $9.6 \%$ of arable unused agricultural land in Ghana as at 2012. Details of this land requirement is summarised in Table 7. The computation is based on the assumption that ethanol would be produced from a combination of cassava and sweet sorghum, in a 50:50 ratio at presently conservative yields. Yield improvements could decrease land use for first generation biofuels but agricultural yields in Ghana and indeed most of sub-Saharan Africa have been poor and gives little room for optimism.

Table 7: Resource requirement for ethanol demand assuming first generation technology

\begin{tabular}{lrrrrrr}
\hline \multirow{2}{*}{ Parameter } & \multicolumn{3}{c}{ Moderate bioenergy } & \multicolumn{3}{c}{ High bioenergy } \\
\cline { 2 - 7 } & $\mathbf{2 0 1 5}$ & $\mathbf{2 0 2 0}$ & $\mathbf{2 0 3 0}$ & $\mathbf{2 0 1 5}$ & $\mathbf{2 0 2 0}$ & $\mathbf{2 0 3 0}$ \\
\hline Ethanol demand (million litres) & $\mathbf{1 2 . 7 3}$ & $\mathbf{1 3 8 . 1 0}$ & $\mathbf{6 4 4 . 6 6}$ & $\mathbf{2 5 . 4 5}$ & $\mathbf{1 3 8 . 1 0}$ & $\mathbf{1 2 8 9 . 3 1}$ \\
Ethanol from Cassava (million litres) & 6.36 & 69.05 & 322.33 & 12.73 & 69.05 & 644.66 \\
Land required for cassava (ha) & 2,121 & 23,016 & 107,443 & 4,242 & 23,016 & 214,885 \\
Ethanol from sweet sorghum (litres) & 6.36 & 69.05 & 322.33 & 12.73 & 69.05 & 644.66 \\
Land required for sweet sorghum (ha) & 3,636 & 39,456 & 184,188 & 7,273 & 39,456 & 368,375 \\
Total land for ethanol (ha) & $\mathbf{5 , 7 5 8}$ & $\mathbf{6 2 , 4 7 2}$ & $\mathbf{2 9 1 , 6 3 0}$ & $\mathbf{1 1 , 5 1 5}$ & $\mathbf{6 2 , 4 7 2}$ & $\mathbf{5 8 3 , 2 6 0}$ \\
\hline
\end{tabular}

Conversion factor: 21.3 MJ per litre.

Yield factors assumed: cassava - 3,000 1/ha; sweet sorghum - 1,750 1/ha.

Source document for conversion factors: European Commission (2007); ethanol yield data was obtained from Afrane (2012) and Sielhorst et al. (2008).

Biodiesel could also be produced from crop residues using second generation technologies, but this technology is even less mature. To produce biodiesel from crop residue, the residue would undergo gasification to form syngas which can then be converted to biodiesel in a FischerTropsch reactor with appropriate catalysts (Sims et al., 2010; IEA, 2010). Because of the challenges currently associated with this type of technology, we have assumed that all biodiesel would be produced from first generation technology in the foreseeable future. Details of land requirements for biodiesel crops are presented in Table 8 with an assumed 50:50 combination of sunflower and jatropha. In the moderate bioenergy scenario, an estimated 513,000 ha of land would be required to cultivate these crops to meet demand for biodiesel for transportation in 2030. This would rise to about 1 million ha in the high bioenergy scenario. Clearly, this calls for urgent measures globally and also in Ghana to continue to promote research into second 
generation technologies to decrease costs and make biofuels attractive socially, environmentally and economically.

Table 8: Resource requirement for biodiesel

\begin{tabular}{lrrrrrr}
\hline \multirow{2}{*}{ Parameter } & \multicolumn{3}{c}{ Moderate bioenergy } & \multicolumn{3}{c}{ High bioenergy } \\
\cline { 2 - 7 } & $\mathbf{2 0 1 5}$ & $\mathbf{2 0 2 0}$ & $\mathbf{2 0 3 0}$ & $\mathbf{2 0 1 5}$ & $\mathbf{2 0 2 0}$ & $\mathbf{2 0 3 0}$ \\
\hline Biodiesel demand (million litres) & $\mathbf{1 3 . 0 8}$ & $\mathbf{1 0 2 . 4 4}$ & $\mathbf{4 6 2 . 1 6}$ & $\mathbf{2 6 . 1 6}$ & $\mathbf{1 0 2 . 4 4}$ & $\mathbf{9 2 4 . 3 1}$ \\
Sunflower oil required (million litres) & 6.54 & 51.22 & 231.08 & 13.08 & 51.22 & 462.16 \\
Land required for Sunflower (ha) & 9,479 & 74,230 & 334,896 & 18,958 & 148,459 & 669,793 \\
Jatropha oil required (million litres) & 6.54 & 51.22 & 231.08 & 13.08 & 51.22 & 462.16 \\
Land required for Jatropha (ha) & 5,031 & 39,399 & 177,753 & 10,062 & 39,399 & 355,505 \\
Total land for biodiesel (ha) & $\mathbf{1 4 , 5 1 0}$ & $\mathbf{1 1 3 , 6 2 8}$ & $\mathbf{5 1 2 , 6 4 9}$ & $\mathbf{2 9 , 0 2 0}$ & $\mathbf{2 2 7 , 2 5 7}$ & $\mathbf{1 , 0 2 5 , 2 9 8}$ \\
\hline
\end{tabular}

Conversion factor: $33.6 \mathrm{MJ}$ per litre.

Yield factors assumed: Sunflower oil - 690 1/ha; jatropha oil - 1,300 1/ha.

Source document for conversion factors: European Commission (2007); biodiesel yield data was obtained from Afrane (2012) and Sielhorst et al. (2008).

\subsection{Emissions savings in bioenergy scenarios}

In the bioenergy scenario, GHG emissions savings would accrue from reduced petroleum fuel consumption due to the introduction of bioenergy into the energy mix. In the moderate bioenergy scenario, about 8 PJ of petroleum fuels would be saved from transportation and electricity generation, rising to $58 \mathrm{PJ}$ in 2030. In the high bioenergy scenario, petroleum fuel savings would begin at $10 \mathrm{PJ}$, and increase to $96 \mathrm{PJ}$ in 2030.

The potential reduction in greenhouse gases is 3 million tonnes of $\mathrm{CO}_{2} \mathrm{e}$ in the moderate scenario and close to 6 million in the high bioenergy scenario in 2030 (Figure 5), equivalent to $14 \%$ reduction relative to total projected emissions in the reference scenario. Close to $96 \%$ of the reductions in 2030 would accrue from the petroleum demand sector. The transformation sector savings are lower because of the assumption that natural gas is the primary electricity generation fuel for electricity in the reference scenario. Also, the roadmap for electricity generation already stipulates a 10\% generation capacity from renewables by 2020, which results in lower emissions from electricity generation. GHG reduction in the transformation sector would be higher if LCO, which has a higher emission factor, is used in the electricity generation mix from 2015 onward. 


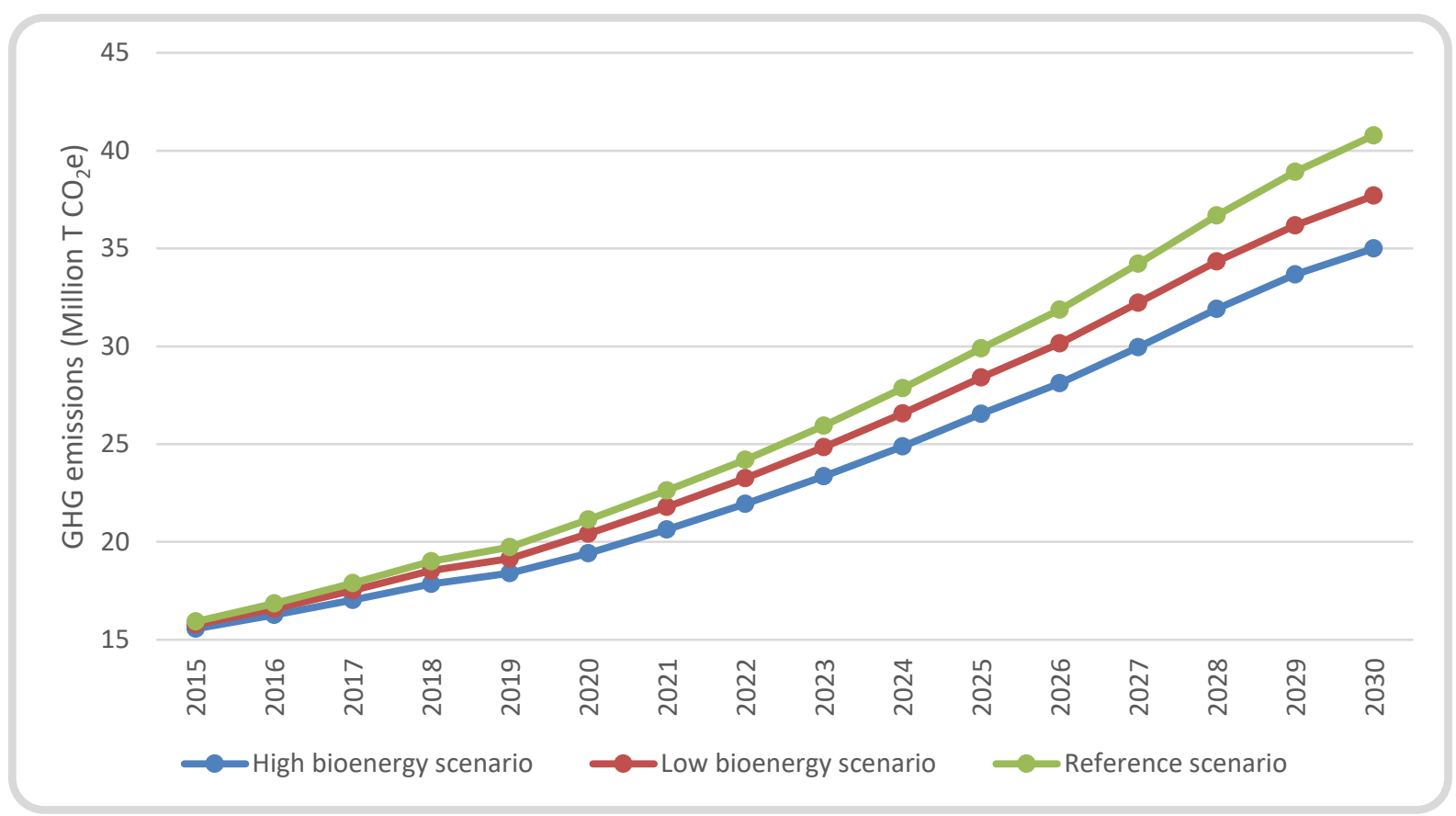

Figure 5: GHG emissions in the various scenarios

\section{CONCLUSIONS}

This paper analysed the effects of bioenergy on Ghana's energy mix from 2015 to 2030 using the LEAP model. Three possible energy scenarios were analysed to study the effects of bioenergy on the energy mix and GHG emissions. The first scenario, referred to as the reference scenario, considered a business-as-usual approach to current energy demand and supply. The two bioenergy scenarios examine the effects of injecting moderate and high bioenergy into the energy mix. In a high bioenergy scenario, electricity from biomass resources would contribute $5.8 \%$ to total electricity generated in 2015 , reducing to $4.0 \%$ by 2030 . Total biofuel demand in the high bioenergy scenario would increase from $1.1 \%$ in 2015 to $21 \%$ in 2030 which is in line with the country's draft bioenergy document which is calling for a $20 \%$ biofuel share in transportation fuels by 2030. In the high bioenergy scenario, the consumption of biofuels would result in the displacement of petroleum, starting from $10 \mathrm{PJ}$ in 2015, and rising to a possible 96 PJ in 2030. Again in the high bioenergy scenario, up to 138 PJ of woodfuel could be saved in 2030 through increased consumption of biogas and increased use of improved cookstoves and charcoal carbonisation technologies. The potential reduction in greenhouse gases for modern bioenergy consumption in all sectors is 3 million tonnes of $\mathrm{CO}_{2} \mathrm{e}$ in the moderate scenario and close to 6 million in the high bioenergy scenario in 2030, equivalent to $14 \%$ reduction relative to total projected emissions in the reference scenario. Feedstock for all bioenergy types, including ethanol, is assumed to come from lignocellulosic biomass. However, if ethanol is not produced from lignocellulosic biomass due to higher production costs, an extra 583,000 ha of land would have to be dedicated to the cultivation of starch and sugar crops for ethanol production. Producing biodiesel from lignocellulosic biomass is also possible, but the technology is even less mature, compared to ethanol. Research support is needed to quicken the pace of commercializing biofuels from lignocellulosic biomass to make the cost attractive for developing countries and thereby free-up land space for agriculture. 


\section{Acknowledgement}

This work was supported with a grant from Danida Fellowship Centre (DFC) of the Danish Ministry of Foreign Affairs, as a part of the project "Biofuel production from lignocellulosic materials - 2GBIONRG”, DFC journal no. 10-018RIS $\varnothing$. For additional information, see http://2gbionrg.dk. 


\section{References}

Afrane, G., 2012. Examining the potential for liquid biofuels production and usage in Ghana. Energy Policy, 40, 444-451.

Antwi, E, Bensah, E. C., Quansah, D. A., Arthur, R., Ahiekpor, J., 2010. Ghana’s biofuels policy: challenges and the way forward, International Journal of Energy and Environment, $1(5), 805-814$.

Appiah, M., Blay, D., Damnyag, L., Dwomoh, F. K., Pappinen, A., Luukkanen, O., 2009. Dependence on forest resources and tropical deforestation in Ghana. Environment, Development and Sustainability, 11(3), 471-487.

Arnold, J. E. M., Köhlin, G., Persson, R., 2006. Woodfuels, livelihoods, and policy interventions: Changing Perspectives. World Development, 34(3), 596-611.

Azad, A. K., Rasul, M. G., Khan, M. M. K., Sharma, S. C. and Hazrat, M. A., 2015. Prospect of Second Generation Biofuel as a Transport Alternative Fuel in Australia. Renewable and Sustainable Energy Reviews, 43, 331-351.

Bautista, S., 2012. A sustainable scenario for Venezuelan power generation sector in 2050 and its costs. Energy Policy, 44, 331-340.

Brasier, K.J., Filteau, M.R., McLaughlin, D.K., Jacquet, J., Stedman, R.C., Kelsey, T.W., et $a l .$, 2011. Residents' perceptions of community and environmental impacts from development of natural gas in the Marcellus shale: a comparison of Pennsylvania and New York cases. Journal of Rural Social Sciences, 26, 32-61.

Brown, D., Shi, J., Li, Y., 2012. Comparison of solid-state to liquid anaerobic digestion of lignocellulosic feedstocks for biogas production. Bioresource Technology, 124, 379-386.

Chandra, R., Takeuchi, H., Hasegawa, T., 2012. Methane production from lignocellulosic agricultural crop wastes: A review in context to second generation of biofuel production. Renewable and Sustainable Energy Reviews, 16, 1462-1476.

Charpentier, A.D., Bergerson, J.A., MacLean, H.L., 2009. Understanding the Canadian oil sands industry's greenhouse gas emissions. Environmental Research Letters, 4, 14005-14016.

Cui, Z., Shi, J., Li, Y., 2011. Solid-state anaerobic digestion of spent wheat straw from horse stall. Bioresource Technology, 102, 9432-9437.

Dagher, L., Ruble, I., 2011. Modeling Lebanon's electricity sector: Alternative scenarios and their implications. Energy, 36, 4315-4326.

Duku, M. H, Gu, S, Hagan, E. B., 2011. A comprehensive review of biomass resources and biofuels potential in Ghana. Renewable and Sustainable Energy Reviews, 15(1), 404-15.

Energy Commission (2010). Draft Bioenergy Policy of Ghana. Energy Commission of Ghana. Available from http://www.energycom.gov.gh/old/downloads/BIOENERGY.pdf

Energy Commission, 2006. Strategic National Energy Plan. Energy Commission of Ghana. Available from http://www.energycom.gov.gh/files/snep/MAIN\%20REPORT\%20final\%20PD.pdf 
Energy Commission, 2013. National energy statistics 2000-2012. The Energy Commission. Accessed 15 September, 2013 from http://www.energycom.gov.gh/files/Ghana_Energy_Statistics_2012_AUG.pdf

EPA-Ghana, 2011a. National greenhouse gas inventory report for 1990-2006. Available from www.adrri.org/assets/.../GH_NIR_GHANA_Final_Version\%20(1).pdf

EPA-Ghana, 2011b. Ghana's second national communication to the UNFCCC. Available from unfccc.int/.../ghana_second_nationalcommunication_final_version.pdf

European Commission, 2007. Report for 2007 under Article 4(1) of Directive 2003/30/EC on the promotion of the use of biofuels or other renewable fuels for transport. European Commission.

Fisk, J.M., 2013. The right to know? State politics of fracking disclosure. Review of Policy Research, 30, 345-365.

Gazull, L., Gautier, D., 2014. Woodfuel in a global change context. Wiley Interdisciplinary Reviews: Energy and Environment, doi:10.1002/wene.115

Ghana Statistical Service, 2012. 2010 Population \& housing census: summary report of final results. Available from

http://www.statsghana.gov.gh/docfiles/2010phc/Census2010_Summary_report_of_final_resu lts.pdf

Ghana Statistical Service, 2014. Provisional gross domestic product 2013. Available from http://www.statsghana.gov.gh/docfiles/GDP/provisional_gdp_2013.pdf

GRIDCO, 2011. Ghana Transmissions and Distribution Master Plan. Ghana Grid Company

Gunn, J.S., Ganz, D.J., Keeton, W.S., 2012. Biogenic vs. geologic carbon emissions and forest biomass energy production. GCB Bioenergy, 4, 239-242.

Haarlemmer, G., Boissonnet, G., Imbach, J., Setier, P., Peduzzi, E., 2012. Second generation BtL type biofuels - a production cost analysis. Energy \& Environmental Science, 5, 84458456.

Hansfort, S., Mertz, O., 2011. Challenging the Woodfuel Crisis in West African Woodlands. Human Ecology, 39(5), 583-595.

Heaps, C.G., 2012. Long-range Energy Alternatives Planning (LEAP) system. [Software version 2014.0.1.29] Stockholm Environment Institute. Somerville, MA, USA. www.energycommunity.org

Hiemstra-van der Horst, G., Hovorka, A. J., 2009. Fuelwood: The "other" renewable energy source for Africa? Biomass and Bioenergy, 33(11), 1605-1616.

Hughes, L., Lipscy, P.Y., 2013. The Politics of Energy. Annual Review of Political Science, $16,449-469$.

IEA, 2010. Sustainable production of second-generation biofuels: potential and perspectives in major economies and developing countries. International Energy Agency, Paris. Available from http://www.iea.org/publications/freepublications/publication/biofuels exec summary.pdf 
IPCC, 2006. 2006 IPCC Guidelines for National Greenhouse Gas Inventories, Prepared by the National Greenhouse Gas Inventories Programme (eds. Eggleston HS, Buendia, L, Miwa K, Ngara T, Tanabe K), IGES, Japan. Available from http://www.ipccnggip.iges.or.jp/public/2006gl/pdf/2_Volume2/V2_0_Cover.pdf

Jahirul, M.I., Rasul, M.G., Chowdhury, A.A. and Ashwath, N., 2012. Biofuels production through biomass pyrolysis - a technological review. Energies 5 (12), 4952-5001.

Kemausuor, F., Kamp, A., Thomsen, S.T., Bensah, E.C., Østergård, H., 2014. Assessment of biomass residue availability and bioenergy yields in Ghana. Resources, Conservation and Recycling, 86, 28-37.

Le Quéré, C., Andres, R.J., Boden, T., Conway, T., Houghton, R.A., House, J.I., et al., 2012. The global carbon budget 1959-2011. Earth System Science Data Discussions, 5, 1107-1157.

Li, Y., Yan, X., Fan, J., Zhu, J., Zhou, W., 2011. Feasibility of biogas production from anaerobic co-digestion of herbal-extraction residues with swine manure. Bioresource technology, 102, 6458-6463.

Liew, L.N., Shi, J., Li, Y., 2012. Methane production from solid-state anaerobic digestion of lignocellulosic biomass. Biomass and Bioenergy, 46, 125-132.

Manatt, R.K., Hallam, A., Schulte, L.A., Heaton, E.A., Gunther, T., Hall, R.B., Moore, K.J., 2013. Farm-scale costs and returns for second generation bioenergy cropping systems in the US Corn Belt. Environmental Research Letters, 8 (3), 035037

McPherson, M., Karney, B., 2014. Long-term scenario alternatives and their implications: LEAP model application of Panama's electricity sector. Energy Policy, 68, 146-157.

Meihui, S., Chiahui, H., Wenyi, L., Chunto, T., Huusheng, L., 2015. A Multi-Years Analysis of the Energy Balance, Green Gas Emissions, and Production Costs of First and Second Generation Bioethanol. International Journal of Green Energy, 12 (2), 168-184.

Mensah, G. S., Kemausuor, F., Brew-Hammond, A., 2014. Energy access indicators and trends in Ghana. Renewable and Sustainable Energy Reviews, 30, 317-323.

Ministry of Energy, 2006. Energy for Poverty Reduction Action Plan for Ghana. A Targeted Approach to Delivery of Modern Energy Services to the Poor. Accra: Ministry of Energy, Ghana. ISBN: 9988-643-64-0

Ministry of Energy, 2011. Renewable Energy Act, 2011: Act 832. Parliament of the Republic of Ghana. Available from

http://energycom.gov.gh/files/RENEWABLE\%20ENERGY\%20ACT\%202011\%20(ACT\%2 0832).pdf

Mohammed, Y. S., Mokhtar, A. S., Bashir, N., Saidur, R., 2013. An overview of agricultural biomass for decentralized rural energy in Ghana. Renewable and Sustainable Energy Reviews, 20, 15-22.

Muhammad Nasir, I., Mohd Ghazi, T.I., Omar, R., 2012. Production of biogas from solid organic wastes through anaerobic digestion: a review. Applied Microbiology and Biotechnology, 95, 321-329.

Mwampamba, T. H., Ghilardi, A., Sander, K., Chaix, K. J., 2013. Dispelling common misconceptions to improve attitudes and policy outlook on charcoal in developing countries. Energy for Sustainable Development, 17(2), 75-85. 
Nathan, H.S.K., Kulkarni, S.S., Ahuja, D.R., 2013. Pipeline Politics-A Study of India's Proposed Cross Border Gas Projects. Energy Policy, 62, 145-156.

Park, N., Yun, S., Jeon, E., 2013. An analysis of long-term scenarios for the transition to renewable energy in the Korean electricity sector. Energy Policy 52, 288-296.

Perez-Padilla, R., Schilmann, A., Riojas-Rodriguez, H., 2010. Respiratory health effects of indoor air pollution. Int J Tubers Lung Dis 14(9), 1079-1086

Peters, G.P., Andrew, R.M., Boden, T., Canadell, J.G., Ciais, P., Le Quéré, C., et al., 2012. The challenge to keep global warming below 2 degrees Celcius. Nature Climate Change, 3 , 4-6.

Pourhashem, G., Adler, P.R., McAloon, A.J., Spatari, S., 2013. Cost and greenhouse gas emission tradeoffs of alternative uses of lignin for second generation ethanol. Environmental Research Letters, 8 (2), 025021

Ramamurthi, P.V., Fernandes, C.M., Nielsen, P.S., Nunes, C.P., 2014. Logistics cost analysis of rice residues for second generation bioenergy production in Ghana. Bioresource technology, 173, 429-438.

Shafiee, S., Topal, E., 2009. When will fossil fuel reserves be diminished? Energy Policy, 37, 181-189.

Shin, H., Park, J., Kim, H., Shin, H., 2005. Environmental and economic assessment of landfill gas electricity generation in Korea using LEAP model. Energy Policy, 33, 1261-1270.

Sielhorst, S., Molenaar, J. W., Offermans, D., 2008. Biofuels in Africa: An Assessment of Risks and Benefits for African Wetlands. Wetlands International, Wageningen

Sijm, J. P. M., 2004. Induced Technological Change and Spillovers in Climate Policy Modeling: An assessment. Available from http://www.ecn.nl/docs/library/report/2004/c04073.pdf

Sims, R.E.H., Mabee, W., Saddler, J.N., Taylor, M., 2010. An overview of second generation biofuel technologies. Bioresource Technology, 101, 1570-1580.

Smith, K. R., Bruce, N., Balakrishnan, K., Adair-Rohani, H., Balmes, J., et al., 2014. Millions dead: how do we know and what does it mean? Methods used in the comparative risk assessment of household air pollution. Annual Review of Public Health, 35, 185-206.

Stephen, J.D., Mabee, W.E., Saddler, J.N., 2012. Will second-generation ethanol be able to compete with first-generation ethanol? Opportunities for cost reduction. Biofuels, Bioproducts and Biorefining, 6, 159-176.

Suganthi, L., Samuel, A.A., 2012. Energy models for demand forecasting - A review. Renewable and Sustainable Energy Reviews, 16, 1223-1240.

Vidic, R.D., Brantley, S.L., Vandenbossche, J.M., Yoxtheimer, D., Abad, J.D., 2013. Impact of shale gas development on regional water quality. Science, 340, 1235009-1235020.

Wu, X., Yao, W., Zhu, J., Miller, C., 2010. Biogas and CH4 productivity by co-digesting swine manure with three crop residues as an external carbon source. Bioresource technology, 101, 4042-4047. 


\section{Supplementary materials}

Appendix 1: Historic energy consumption and demographics (2001-2010)

\begin{tabular}{llrrrrrrrrrr}
\hline Energy Indicator & Unit & $\mathbf{2 0 0 1}$ & $\mathbf{2 0 0 2}$ & $\mathbf{2 0 0 3}$ & $\mathbf{2 0 0 4}$ & $\mathbf{2 0 0 5}$ & $\mathbf{2 0 0 6}$ & $\mathbf{2 0 0 7}$ & $\mathbf{2 0 0 8}$ & $\mathbf{2 0 0 9}$ & $\mathbf{2 0 1 0}$ \\
\hline Total final energy & PJ & 226 & 222 & 207 & 213 & 213 & 217 & 221 & 218 & 240 & 237 \\
Total electricity consumed & GWh & 6564 & 6219 & 4603 & 4593 & 5259 & 6657 & 5720 & 6330 & 6410 & 7124 \\
Electricity generation - large hydro & GWh & 6609 & 5036 & 3886 & 5281 & 5629 & 5619 & 3727 & 6195 & 6877 & 6996 \\
Electricity generation - thermal & GWh & 1250 & 2237 & 1996 & 758 & 1159 & 2811 & 3251 & 2129 & 2081 & 3171 \\
Gasoline consumption & PJ & 24 & 26 & 22 & 26 & 24 & 23 & 25 & 25 & 32 & 33 \\
Diesel consumption & PJ & 31 & 32 & 34 & 38 & 40 & 42 & 52 & 49 & 58 & 58 \\
Firewood consumption & PJ & 153 & 154 & 121 & 113 & 101 & 88 & 75 & 69 & 65 & 64 \\
Charcoal consumption & PJ & 35 & 36 & 37 & 38 & 38 & 39 & 39 & 39 & 39 & 40 \\
Population & Million & 19.4 & 19.8 & 20.3 & 20.8 & 21.3 & 21.8 & 22.3 & 22.9 & 23.4 & 24.7 \\
\hline Source: Adapted from Energy Commission $(2013)$ & & & & & &
\end{tabular}

Appendix 2: Assumptions of demographic and economic indicators

\begin{tabular}{lcccccc}
\hline Parameter & Unit & $\mathbf{2 0 1 0}$ & $\mathbf{2 0 1 5}$ & $\mathbf{2 0 2 0}$ & $\mathbf{2 0 2 5}$ & $\mathbf{2 0 3 0}$ \\
\hline Households & Millions & 5.6 & 6.4 & 7.1 & 7.8 & 8.4 \\
Urbanisation rate & $\%$ & 56.2 & 58.4 & 60.6 & 62.8 & 65 \\
GDP & US\$ & 32.2 & 52.5 & 76.8 & 105.2 & 137.6 \\
\hline
\end{tabular}

